\title{
Radiofrequency Diathermy for Rhinogenic Headache
}

\author{
Chang Hwan Choi, Kwang Ho Jin, Min Woo Park, and Myeong Sang Yu \\ Department of Otorhinolaryngology, Konkuk University School of Medicine, Chungju, Korea
}

\section{고주파 투열 치료를 이용해 치료한 비성 두통}

최창환 · 진광호· 박민우· 유명상

건국대학교 의학전문대학원 이비인후과학교실

\author{
Received June 16, 2014 \\ Revised August 14, 2014 \\ Accepted August 19, 2014 \\ Address for correspondence \\ Myeong Sang Yu, MD, PhD \\ Department of Otorhinolaryngology, \\ Konkuk University \\ School of Medicine, \\ 82 Gugwon-daero, \\ Chungju 380-704, Korea \\ Tel $+82-43-840-8280$ \\ Fax $+82-43-843-6165$ \\ E-mail dryums@gmail.com
}

\begin{abstract}
Rhinogenic headache is a headache or facial pain syndrome secondary to mucosal contact points or rhinogenic causes in the absence of rhinitis/sinusitis. The authors report a case of atypical rhinogenic headache in a 72-year-old woman who presented with recurrent right side headache, which was aggravated by nasal breathing. A computed tomographic scan showed no evidence of rhinosinusitis and mucosal contact points. However, during nasal endoscopy, she had multiple pain-trigger points on the septum and lateral nasal wall. Treatment involved endoscopic reduction and radiofrequency diathermy of the pain-trigger point. Postoperatively, the headache was successfully relieved, and there was no evidence of recurrence. In this article, the authors present surgical option for the treatment of atypical rhinogenic headache.
\end{abstract} Korean J Otorhinolaryngol-Head Neck Surg 2015;58(3):205-8

Key Words Radiofrequency diathermy $\cdot$ Rhinogenic headache.

\section{서 론}

비성 두통은 비강이나 부비동의 직접적인 원인에 의해 발 생하는 이차성 두통으로서 그 원인으로 비부비동염이나 비 내 접촉점이 있는 경우, 혈관 운동성 비염 등을 들 수 있다. 급 성 또는 만성 비부비동염에 의한 통증은 두통과 안구 주위 둔통의 원인 중 하나로, 비내시경이나 영상 검사 등에서 비 부비동염의 소견이 관찰되고 비부비동염이 심해질 경우 두 통이 더 심해지는 양상으로 비부비동염의 성공적인 치료시 약 7 일 이내 호전을 보이는 것을 말한다. 접촉점 두통은 비내 시경이나 전산화단층촬영에서 접촉점이 관찰되는 경우로, 접촉면에 국소 마취시 5 분 이내 통증이 사라지고 접촉면 교 정시 7일 이내 의미 있는 임상 증상의 호전이 있는 경우 생각 해 볼 수 있다. ${ }^{1)}$ 물론 급성이나 만성 부비동염 등 염증의 증 거가 있는 경우엔 접촉점 두통의 진단에서 제외된다. 저자들 은 수년간의 약물 치료와 수술적 치료에도 반응하지 않는, 접촉점은 관찰되지 않으나 비강내 국소적 마취에 의해 통증
이 경감되는 양상의 비성 두통에 대하여 고주파 투열 치료 후 증상 호전된 1 예를 치험하여 문헌 고찰과 함께 보고하고 자 한다.

\section{증 계}

고혈압 외 특이 과거력이 없는 72세 여자 환자로 약 10년 전부터 지속된 비강 및 우측 안구 주위 통증을 주소로 본원 이비인후과에 내원하였다. 환자의 표현에 따르면 통증은 숨 을 쉴 때마다 우측 안각에서 눈 위쪽 반시계 방향으로 뻗어 나가는 양상이었다. 통증의 정도는 visual analogue scale(VAS 0: no pain 10: very severe pain)로 측정하였고 9 10점에 해당 하였다.

이러한 증상은 내원 약 11 년 전부터 발생하여 인근 이비인 후과에 방문하여 만성 부비동염 및 비중격 만곡증 추정하에 양측 내시경부비동수술 및 비중격 교정술을 시행받았으나 통증은 지속되었다. 8년 전 같은 증상으로 본원 신경과 방문 

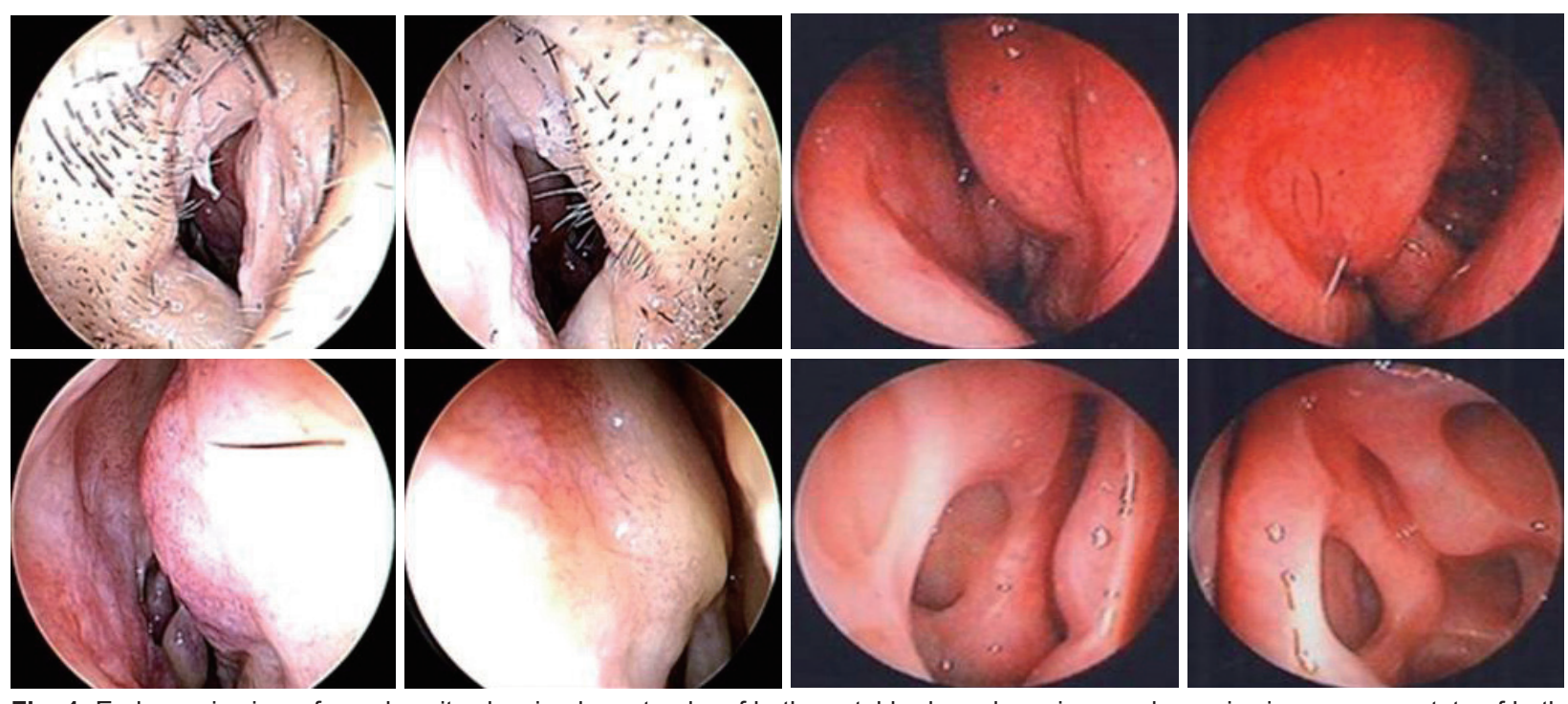

Fig. 1. Endoscopic view of nasal cavity showing hypertrophy of both septal body and previous endoscopic sinus surgery state of both middle meatus.
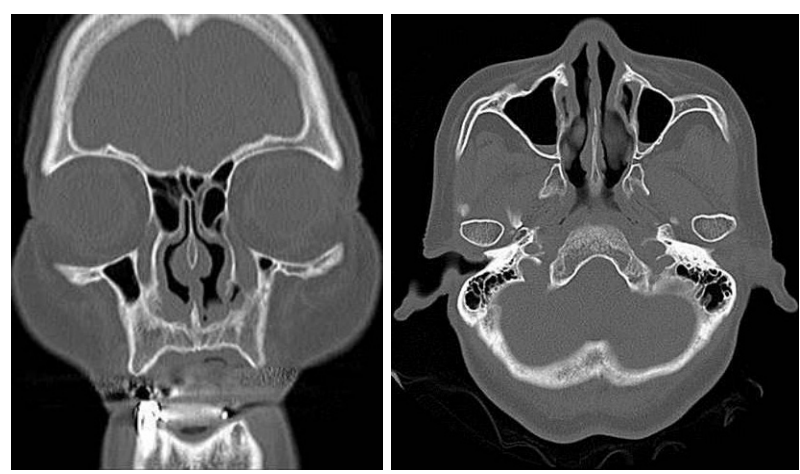

Fig. 2. Preoperative computed tomography of paranasal sinus: showing the sinus itself contained air, with no evidence of any mucosal disease or collection of mucus. And no evidence of any contact point of nasal mucosa.

후 혼합성 두통 추정하에 소염 진통제를 투여 받았으나 투약 시에만 일시적 호전이 있을 뿐 재발과 호전이 반복되었고, 약 3년 전엔 빈코증후군(empty nose syndrome) 진하에 인근 이 비인후과에서 내시경하 비강용적감술(microplasty)을 시행 받은 후 몇 개월간 두통의 호전이 있었으나 다시 재발하였다. 내원 1년 전 지속적인 우측 안구 주위 통증과 안검하수가 있 어 본원 신경과에서 근무력증 추정하에 pyridostigmine (Mestinon, KOREAN DRUG CO., LTD., Seoul, Korea)을 약 3개 월간 투여 받았으나 증상의 호전은 없었고, 또한 내원 수개월 전 삼차 신경통 의심하여 carbamazepine(Tegretol CR tab, Novartis Korea, Seoul, Korea)을 약 2개월간 투여 받았으나 증상의 호전은 보이지 않았다.

환자는 호흡시 심해지는 비강과 우측 안구 주위 통증, 약간 의 코막힘과 점액성 비루를 주소로 본원 이비인후과에 내원
하였다. 이학적 검사를 시행하였으며 비내시경상 과거에 시 행받은 내시경하 비강용적감소술로 인해 양측의 비강 입구 가 좁아진 상태 및 비강 바닥이 불룩하게 돌출된 소견이 관 찰되었다. 또한 양측 중비도는 내시경부비동수술이 시행된 상태로 염증 소견과 같은 특이 소견은 관찰되지 않았으며 양 측 비중격의 비대 소견이 관찰되었다(Fig. 1). 그 외 구강 및 안 면부, 경부에 특이 이상 소견은 관찰되지 않았다.

만성 부비동염 감별을 위하여 부비동 전산화단층촬영을 시행하였다. 부비동 전산화단층촬영상 골막의 결손이나 점 막 병변 소견은 보이지 않았다(Fig. 2).

비내시경하 진찰 중 탐침으로 우측 비중격의 후상방 부위를 접촉시 통증이 크게 증가하는 모습을 보여(Fig. 3), 비강 점막 에서 기시하는 통증의 양상과 흡기시 증가하는 비강과 안구 주위 통증의 양상으로 비성 두통으로 추정 진단하였다. 이후 작은 크기의 얇은 거즈에 국소마취제를 도포한 후 우측 비중 격 후상방 부위 점막에 부착하여 환자의 반응을 관찰하였으 며 그 후 통증은 없어지는 반응을 보였다. 비성 두통 진단하 수술적 치료로 비점막 축소술을 부분 마취로 진행하였고, 수술시 마취하지 않은 상태에서 다시 탐침을 이용하여 통증 유발점을 확인한 후 흡입 절삭기(microdebrider)를 이용하 여 통증이 기시하는 비중격 점막의 표면을 포함하여 부분적 으로 제거하였다. 수술 후 약 1 개월째 비강과 우측 안구 주 위의 통증은 VAS 1 2점에 해당될 정도로 호전되었으나 수 술 후 6개월 뒤 재발하였고 통증의 정도는 VAS 7 8점에 해 당하였다.

그 후 다시 비강내 점막에 국소마취제 검사를 시행하였고, 검사시 우측 중비갑개와 외측 벽을 탐침으로 자극시 통증이 


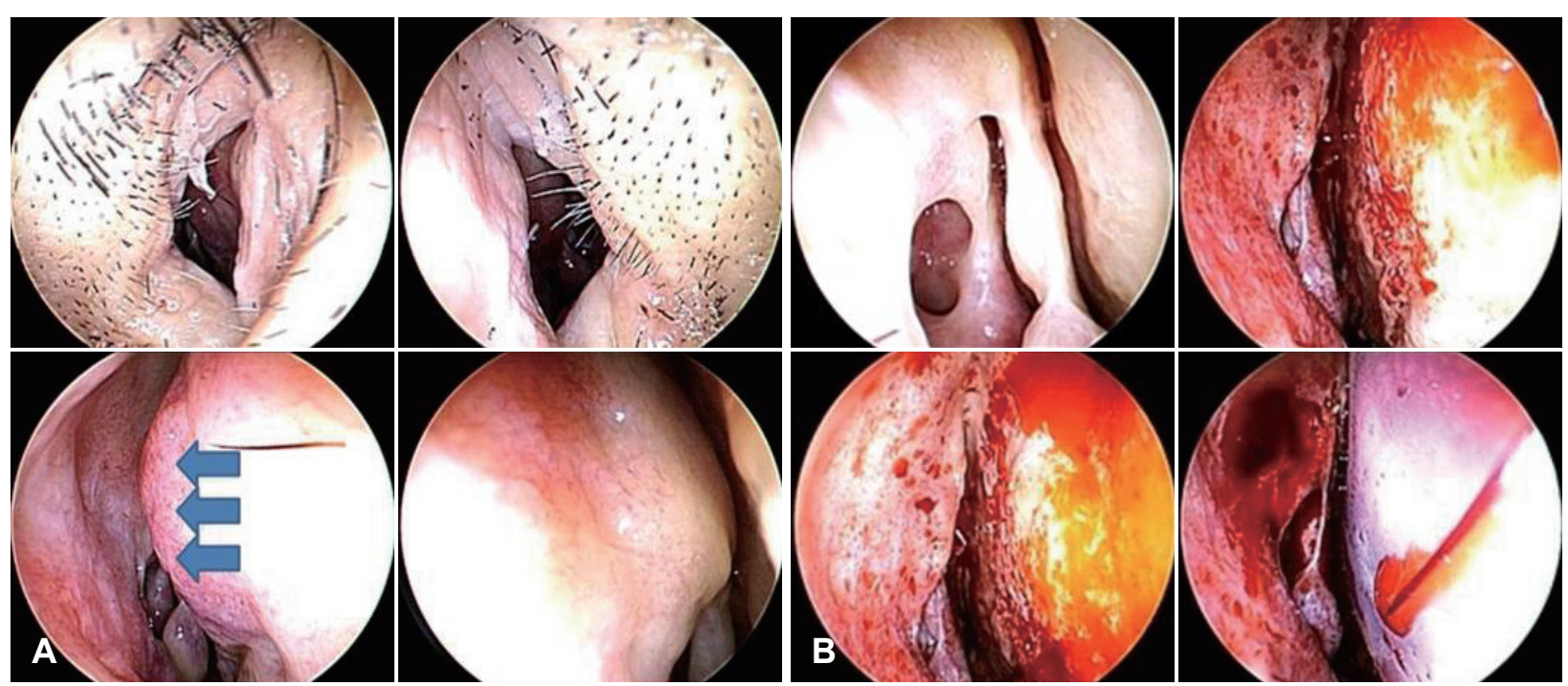

Fig. 3. Preoperative endoscopic view of nasal cavity (septal body reduction) (A). Postoperative endoscopic view of nasal cavity (B). Microdebrider assisted septal body reduction was performed (arrows).
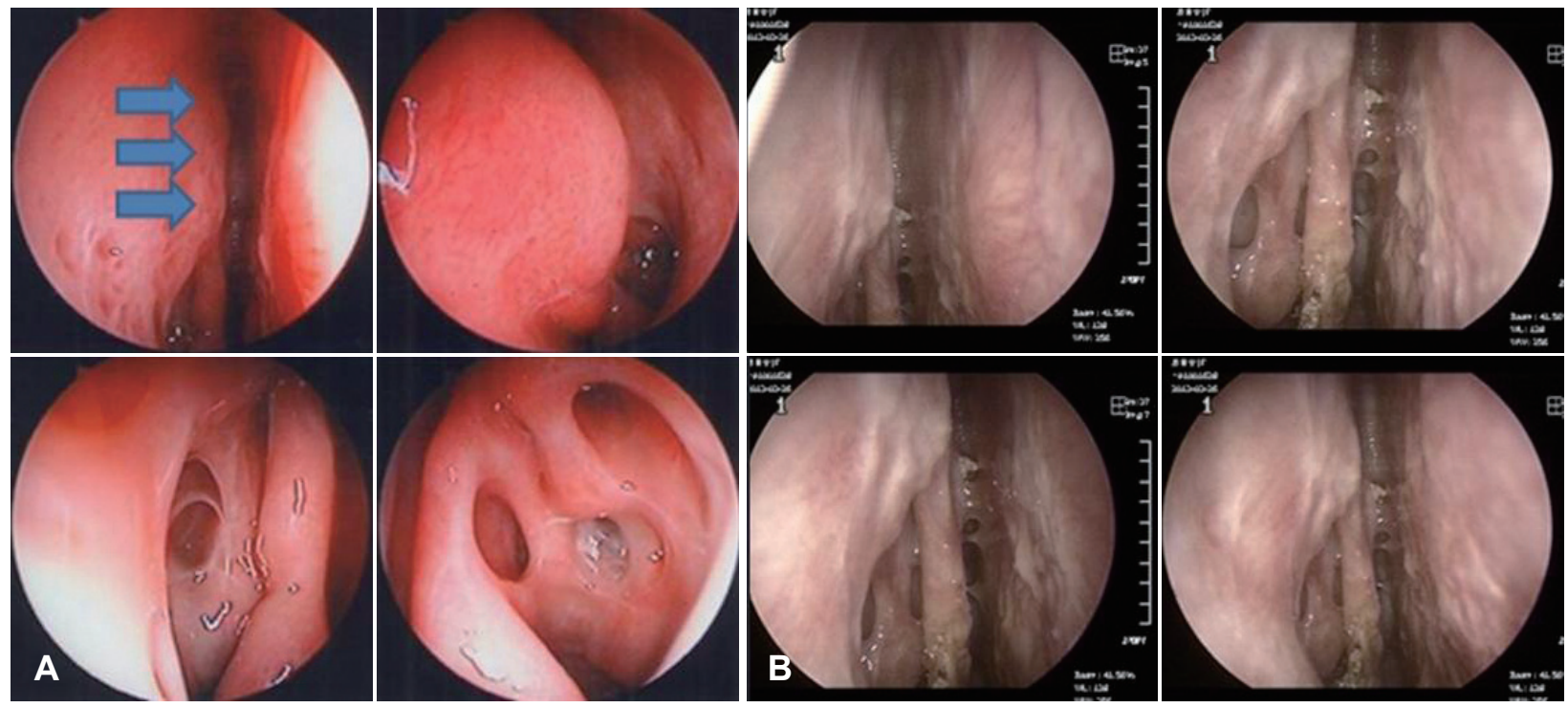

Fig. 4. Preoperative endoscopic view of nasal cavity (radiofrequency diathermy) (A). Postoperative endoscopic view of nasal cavity (about 6 months later) (B). Radiofrequency diathermy was performed on right middle turbinate \& right lateral nasal wall (arrows).

크게 증가되며 국소 마취시 통증이 없어지는 양상을 보였다 (Fig. 4). 다시 수술을 시행하였고 수술시 다시 탐침을 이용 하여 통증 유발점을 확인하였으며, 부분 마취하 통증 부위에 generator 780-II(Select-sutter-medizintechnik, level 2.5, 10 w; Sutter medizintechnik, Freiburg im Breisgau, Germany)의 monopolar ball tip을 이용하여 고주파 투열 치료를 시행하였다. 수술 약 21 개월이 지난 현재까지 통증은 VAS 1 2점에 해당될 정도로 호전된 상태로 재발이나 특별한 합 병증은 없이 외래 경과관찰 중이다.

\section{고 찰}

비성 원인에 대한 두통은 1888 년경 처음으로 언급되기 시 작하여, ${ }^{2}$ 1980년 발표된 한 논문에서는 중비갑개와 비중격의 점막이 접촉하여 이차적으로 통증을 일으키는 것을 'middle turbinate headache syndrome'으로 명명하기도 하였다. ${ }^{3)}$ 그 후 한 연구에서는 중비갑개의 전단부에 분포된 삼차신경의 분지인 전사골신경(anterior ethmoidal nerve)을 자극했을 시 상하 도르래 신경(trochlear nerve)이 분포하는 내안각과 안구 주위에 통증이 발생한다고 보고하였다. ${ }^{4)}$ 2004년 International Headache Society ${ }^{1)}$ 에서는 두통을 크게 원발 두통, 이차성 
두통, 뇌 신경통 및 기타 두통으로 분류하였고, 그 중 이차성 두통의 하나인 비성 두통 중 비부비동염 외 통증을 유발할 것으로 생각되는 비중격 만곡증이나 비갑개의 비후, 점막의 접촉점 등은 두통의 원인으로 충분히 증명되지 못한 것으로 기술하고 있다.

점막 접촉점 두통의 원인은 아직 명확히 증명되지 않았으 나, 한 연구에서는 비부비동 점막에 대한 자극이 신경 전달 물질 중 하나인 substance $\mathrm{P}$ 를 통해 중추신경계로 전달되 고, 이에 대해 antidromic conduction으로 삼차신경 1, 2분지 부위의 신경 전달 물질 분비를 통해 혈관 확장을 일으켜 연 관통이 나타난다고 보고하였다. ${ }^{5)}$ 또 다른 연구에서는 비내 점막의 삼차 신경이 안면부 통증을 일으키는 피부 표면의 신 경들과 함께 대뇌를 자극하여 발생한다고 주장하기도 하였다. ${ }^{6}$ 비내시경이나 전산화단층촬영 검사에서 비강의 구조적인 이상으로 인해 접촉점이 확인되며 국소적 마취로 통증이 감 소하는 경우 수술적인 치료를 고려해 볼 수 있다. 물론 그 전 에 반드시 두통을 유발할 수 있는 여러 질환의 감별진단 또 한 필요하며 이를 위해선 환자의 자세한 병력 청취 및 두통의 양상 등을 세심하게 살필 필요가 있다. 접촉점 두통에 대해 한 국내 연구에서는 10 명의 접촉점 두통 환자에 대하여 비중격 교정술, 하비갑개 절제술 등 수술적 치료를 시행하여 두통의 빈도나 강도 등이 술전보다 유의하게 감소하였다고 보고하였 으며,' 두통과 안면통이 있던 한 환자에서 비중격극을 제거 한 후 두통이 호전된 증례를 보고하기도 하였다. ${ }^{8)}$ 한 해외 연 구에서도 60 명의 환자를 대상으로 중비갑개의 수술적 제거로 접촉점을 제거하여 좋은 결과를 얻었다고 보고하였다. ${ }^{9)}$

본 증례에서는 수년간 여러 두통 질환 추정하에 약물 치료 를 하였으나 호전과 악화가 반복되었고, 만성 비부비동염, 빈 코증후군(empty nose syndrome) 등 추정하에 수술적 치료 하였으나 두통이 재발하였던 환자로 그 병력과 통증의 양상 으로 비성 두통을 추정해 볼 수 있었다. 이것은 비강내 기류 가 줄어들면서 비강내 통증이 기시하던 점막에 자극이 줄어 일시적으로 통증이 감소했을 것으로 생각되나 근본적으로 비강 점막의 자극에 의한 신경 전달 문제가 해결되지 못하였 기 때문에 재발한 것으로 추측된다. 이 증례의 의의는 비강 자극시 한 부위에 심한 통증이 유발되며 국소 마취 검사시 통증이 사라지는 점막 접촉점 두통의 양상을 보이나, 비내시 경이나 전산화단층촬영상 뚜렷한 비내 접촉점은 관찰되지 않았던 드문 경우라 할 수 있겠다. 또한 이러한 경우에서 비 성 두통의 발생 기전 중 하나로 추측되는 신경 전달 물질의 분비를 막기 위해 고주파 투열 치료를 시행하였고 그 결과 증상의 호전을 경험하였다는 것이다. 첫 번째 수술시 우측
후상방 비중격 부위가 비대한 소견을 보이고, 탐침을 이용해 접촉시 통증이 크게 증가하며 국소마취제를 도포한 거즈를 부착했을 때 통증이 사라진 것으로 보아 접촉점(contact point) 으로 생각되어 흡입 절삭기를 시용하여 부분적으로 제거하였 으나 통증이 재발하였다. 이후 다시 시행한 탐침과 국소 마취 제를 이용한 검사에서 전사골신경(anterior ethmoid nerve) 이 분포하는 것으로 생각되는 우측 비강의 외측 벽과 중비갑 개에서 통증이 유발되어 넓게 그 부위에 고주파 투열 치료를 시행하였다. 본 증례에서 고주파 투열 치료를 시행한 것은 전 사골신경 말초 분지를 차단시키는 신경절제술 개념에 포함될 것으로 생각되며, 첫 수술시엔 우측 비중격의 비대해진 점막 부위를 접촉점으로 생각하고 흡입 절삭기를 사용하여 용적 을 감소시키는 목적으로 수술을 하였으나 결국 점막의 제거 가 신경절제술의 효과도 보였을 것으로 생각된다. 또한 처음 부터 신경절제술의 개념으로 접근하여 좀더 넓게 전사골신 경의 근위부를 제거했다면 더 좋은 결과도 생각해 볼 수 있을 것이다. 비성 두통의 원인 및 치료는 아직까지 명확하게 밝혀 진 바가 없기 때문에 고주파 투열 치료가 효과적인 치료 방법 인지에 대한 명확한 근거는 부족하지만 최초로 고주파 투열 치료로 효과적으로 치료된 비성 두통 증례라는 것에 의의를 둘 수 있겠으며, 본 증례에서처럼 비강 점막에서 유발되는 신 경 전달 물질의 과도한 분비를 막는 방법으로 고주파 투열 치 료는 유용한 방법이 될 수 있을 것으로 생각된다.

\section{REFERENCES}

1) Headache Classification Subcommittee of the International Headache Society. The International Classification of Headache Disorders: 2nd edition. Cephalalgia 2004;24 Suppl 1:9-160.

2) Roe JO. The frequent dependence of persistent and so-called congestive headaches upon abnormal conditions of the nasal passages. Med Record 1888;34:200-4.

3) Morgenstein KM, Krieger MK. Experiences in middle turbinectomy. Laryngoscope 1980;90(10 Pt 1):1596-603.

4) Wolf G, Saria A, Gamse R. [New aspects of the autonomic innervation of human nasal mucosa]. Laryngol Rhinol Otol (Stuttg) 1987;66(3):149-51.

5) Sluder G. Etiology, diagnosis and prognosis of treatment of sphenopalatine ganglion neuralgia. J Am Med Assoc 1913;61(13 Pt 2):1201-6.

6) Greenfield HG. Headache and facial pain associated with nasal and sinus disorders: a diagnostic and therapeutic challenge. Insights Otolaryngol 1990;5:1-4.

7) Lee JH, Ahn TJ, Ahn SY, Bae WY. Surgical treatment of contact point headache. J Rhinol 2010;17(1):29-32.

8) Cho WW, Eom TW, Kim JH. A case of mucosal contact point headache caused by septal spur. Korean J Otorhinolaryngol-Head Neck Surg 2014;57(6):407-10.

9) Albirmawy OA, Elsherif HS, Shehata EM, Younes A. Middle turbinate evacuation conchoplasty in management of contact-point rhinogenic headache in children. Int J Clin Pediatr 2012;1(4-5):115-23. 